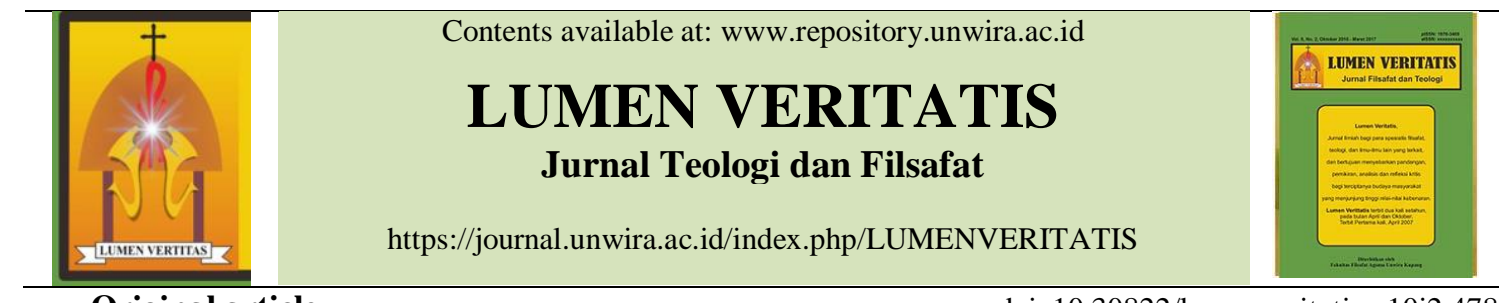

Original article

doi: 10.30822/lumenveritatis.v10i2.478

\title{
PERJALANAN JIWA KE "KAMPUNG LELUHUR" KONSEP KEMATIAN MENURUT KEPERCAYAAN ASLI MASYARAKAT SUMBA (MARAPU) DAN PERJUMPAANNYA DENGAN AJARAN KATOLIK
}

\author{
Herman Punda Panda \\ Program Studi Ilmu Filsafat, Fakultas Filsafat, Universitas Katolik Widya Mandira \\ Email: hermanpanda02@gmail.com
}

\begin{abstract}
This study answers a phenomenon of double funeralrite that often occurs among the Catholics who converted from Marapu, the ethnic religion of the people of Sumba. Double funeralrite is the practice of funeral ceremonies consisting of official liturgy of the Catholic Church and spontaneously followed by a number of Marapu rites. Such a practice indicates a dualism of belief, in the sense that people have embraced the Catholic faith but are still attached to the elements of their old beliefs. In this study the author investigates in depth both the funeral rites according to Marapu and the double practice phenomenon in funeral ceremonies of Catholics who converted from Marapu. The main purpose of this research is to find parallels and intersections between Catholic's concept of life after death and that of Marapu's. Discussion and analysis of the data prioritizes the meaning behind each verbal and non-verbal expression. The meaning of prayers, rituals and symbols used in funeral according to Marapu reveals universal values that parallel to the values contained in Catholic teaching. According to Marapu belief, death is the return of the soul towards "ancestral village", which is the final resting place of souls after death. This return is believed to be a long journey before arriving at the ancestral village. Prayers and ceremonies carried out by humans aim to help the soul to enter the ancestral village. This concept parallels to the Catholic understanding of soul purification after death before entering the eternal happiness in Heaven. Such parallels allow a construction of the encounter between Catholic teachings and Marapu ones about life after death.
\end{abstract}

Keywords: Hidup setelah mati, Upacara, Marapu, Katolik, Perjumpaan

\section{Pendahuluan}

Sebelum Gereja Katolik masuk di Sumba, orang-orang Sumba secara turun temurun telah menganut agama asli yang disebut Marapu. Agama ini dianut oleh penduduk asli di seantero pulau Sumba, walaupun orang-orang Sumba terdiri atas sejumlah sub-etnis dengan dialek yang berbeda-beda. Penganut agama asli Marapu percaya akan adanya Sang Pencipta yang disebut Magholo-Marawi
(Pencipta dan pembuat) dan roh-roh yang menjadi pengantara antara manusia dan Sang Pencipta. Roh-roh itu dibedakan atas arwah leluhur dan rohroh yang telah ada lebih dahulu dan hidup abadi. Doa dan pemujaan yang dilakukan manusia melewati pengantara yang bertingkat-tingkat, mulai dari arwah leluhur lalu ke roh yang lebih tinggi dan akhirnya kepada Sang Pencipta. 
Penelitian ini diadakan di desa Karuni, Kabupaten Sumba Barat Daya, NTT. Metode yang digunakan adalah metode kualitatif. Metode kualitatif sejalan dengan tujuan penelitian ini yakni mencari makna dan konsep ${ }^{1}$ di balik ritual dan doa penguburan orang mati. Sebagai penelitian ilmiah, dipentingkan suatu cara berpikir rational, sistematis dan empiris. Segala fenomen baik simbol maupun ungkapan verbal yang berkaitan dengan ritual penguburan orang mati diselidiki dengan cermat. Dari wawancara dan pengamatan terlihat hubungan logis antara unsur-unsur simbolis dan verbal karena semuanya terikat pada makna tertentu yang hendak diungkapkan. Peneliti berusaha mengonstruksi suatu makna di balik semuanya.

Teknik pengumpulan data meliputi wawancara mendalam dengan sebelas orang informan yang usianya lima puluh tahun ke atas. Kesebelas informan ini terdiri atas enam orang Marapu dan lima orang Katolik. Dalam penelitian ini, juga diadakan pengamatan atas dua event upacara pemakaman dan pengamatan atas kampung adat di desa Karuni dan lokasi pemakaman di pelataran kampung adat.

Di dalam penuturan para informan diungkapkan sejumlah unsur ritual, benda-benda yang digunakan dan peristiwa-peristiwa, yang melalui pertanyaan lebih lanjut ditelusuri lagi maknanya. Temuan-temuan dalam observasi di lokasi yakni menyaksikan ritual penguburan dan mengamati perkampungan adat, merupakan pula tambahan yang melengkapi dan

\footnotetext{
${ }^{1}$ Iskandar, Metodologi Penelitian Kualitatif (Jakarta: 2009), hlm. 11-12.
}

memperdalam data yang didapat melalui wawancara. Kadang-kadang hal-hal yang diobservasi menjadi pula pokok dalam wawancara dengan para informan. Dari data yang terhimpun itu terungkap konsep "doktrinal" yang melatarbelakangi segala ritual dan doa di sekitar kematian dan pemakaman. Data ini menjadi bahan yang dianalisis lebih lanjut untuk melihat unsur-unsur yang sejajar dengan doktrin Katolik tentang status jiwa setelah kematian.

\section{Sejarah Singkat Perjumpaan}

Pada awal perjumpaan dengan para missionaris Katolik masyarakat Sumba amat terbuka dan menyerahkan anak-anak mereka untuk dibaptis. Tetapi dalam waktu yang tidak terlalu lama, para kepala suku dan masyarakat menahan anak-anak mereka dan mulai jarang terjadi pembaptisan. Alasannya karena mereka takut Marapu. ${ }^{2}$ Strategi yang kemudian dijalankan para misionaris adalah mendirikan sekolah dan asrama untuk mendidik anak-anak Sumba dalam hal membaca dan menulis, sekaligus pendidikan agama. Anak-anak yang dididik itu diharapkan kelak menjadi pewarta Injil bagi masyarakat Sumba.

Namun demikian dalam perjalanan waktu tidak dicapai hasil yang diharapkan. Bahkan para missionaris menghadapi tantangan-tantangan berat serta mengeluarkan banyak biaya. Atas alasan ini, pimpinan Gereja Katolik waktu itu memutuskan untuk menutup karya misi di Sumba dan menarik kembali para missionaris pada tahun

\footnotetext{
${ }^{2}$ Henricus Haripranata, Ceritera Sejarah Gereja Katolik Sumba dan Sumbawa, (Ende: Nusa Indah, 1984), hlm. 129.
} 
1898. Karya misi Katolik di Sumba terhenti selama 23 tahun dan selama periode tersebut sebagian besar orangorang yang pernah dibaptis kembali lagi ke agama asli Marapu. Baru pada tahun 1921 karya misi dilanjutkan oleh para missionaris SVD. Missionaris SVD berkarya di Sumba sampai tahun 1958 ketika misi Sumba diambil alih oleh Redemptoris. Dalam pelayanan para missionaris Redemptoris yang berkelanjutan, Gereja lokal Keuskupan Weetebula berdiri pada tahun 1969.

Pendekatan para missionaris terhadap kepercayaan Marapu pada awalnya bersifat negatif dalam arti mereka ingin menghapus "kekafiran" dan menggantinya dengan kekristenan. Pendekatan budaya dan penggunaan bahasa daerah hanya sekadar bertujuan agar pewartaan iman dapat dipahami dengan baik oleh penerimanya. Setelah Keuskupan Weetebula berdiri dan Gereja lokal itu dilayani oleh lebih banyak pastor pribumi, juga sejalan dengan semangat Konsili Vatikan II, inkulturasi semakin dipikirkan dan diusahakan.

Salah satu percobaan penting yang patut dicatat adalah usaha mengangkat dan memodifikasi ritual Marapu ke dalam ibadat dan pewartaan Gereja dengan diberi makna dan isi yang baru yang berasal dari iman Katolik. Ritual yang sudah pernah diangkat adalah zaigho. Zaigho adalah upacara dengan serangkaian doa yang dinyanyikan dalam bahasa indah (tenda), diiringi gong dan gendang yang meditatif. Selama doa dinyanyikan, sejumlah perempuan membawakan tarian. Hal ini berlangsung semalam suntuk di pelataran rumah adat, selama tiga sampai tujuh malam. Dan terdapat pula kesempatan orang-orang yang telah dipilih (mewakili beberapa clan) untuk "menyumbangkan suara" (tauna li'i) berupa penyampaian intensi doa, juga dalam bahasa yang indah dan kemudian dinyanyikan oleh pemimpin ritual. Bentuk ritual seperti ini ketika diangkat dalam ibadat Katolik, disederhanakan, dimodifikasi, lalu diberi makna baru dan isi doa yang dinyanyikan adalah doa-doa Katolik. Lamanya tidak lagi semalam suntuk melainkan hanya beberapa jam.

Di lingkungan Gereja Kristen Sumba (Protestan) dikembangkan pula hal yang sama. Seperti dicatat F.D. Wellem, upacara tauna li' $i$ digunakan dalam upacara gerejawi. ${ }^{3}$ Dalam hal ini upacara tersebut juga dimodifikasi dari bentuk aslinya dan digunakan pada hari raya Natal, Paskah dan perayaan lainnya. Pada awal upacara, seorang wakil umat menanyakan motif dan tujuan perayaan, yang kemudian dijawab oleh pemimpin ibadat dengan menjelaskan maksud dan tujuan perayaan tersebut. Dialog seperti itu merupakan bentuk pewartaan. Semuanya dibawakan dalam baitan bahasa pantun atau syair yang indah. Selain tauna li' $i$, digunakan pula upacara panggara tau ("Siapakah anda"), khusus di Sumba Timur, yaitu suatu upacara berbentuk dialog yang biasa digunakan dalam adat Sumba untuk menyatakan perdamaian antara dua pihak yang berperang. Upacara ini digunakan oleh GKS untuk menerima para petobat baru yang melalui pembaptisan diperdamaikan dengan Kristus. ${ }^{4}$

Usaha-usaha seperti disebutkan di atas belum berhubungan langsung

${ }^{3}$ F.D.Wellem, Injil dan Marapu, suatu Studi Historis-Teologis tentang Perjumpaan Injil dengan

Masyarakat Sumba pada Periode 1876-1990, (Jakarta: BPK Gunung Mulia, 2004), hlm. 260.

${ }^{4}$ Ibid., hlm 269-270. 
dengan hal doktrinal (ajaran iman). Usaha perjumpaan pada tingkat doktrinal (ajaran iman Kristen dan ajaran Marapu) baru sedikit. Perjumpaan seperti itu, hemat kami, penting sebelum tiba pada penerapan langsung dalam ibadat. Untuk itu diperlukan suatu keberanian menerima adanya kontinuitas dari kepercayaan lama ke agama kristen, tidak hanya menekankan kebaruan agama kristen. ${ }^{5}$

\section{Problem perjumpaan}

Setelah seratus tahun lebih Kekristenan masuk di pulau Sumba, terdapat perjumpaan spontan berupa tumpang tindih antara kepercayaan Marapu dan iman kristen dalam masyarakat yang sama. Usaha kontekstualisasi menjadi mendesak antara lain untuk mengatasi tumpang tindih dan praktek ganda tersebut. Beberapa persoalan yang perlu diatasi adalah: pandangan Gereja atas Marapu, irisan antara kampung adat dan komunitas gerejawi, ritual Marapu dan doa kristen, pandangan atas derita dan kemalangan, dan problem penerjemahan konsep-konsep teologi.

\section{Pandangan Gereja atas Marapu}

Pandangan para misionaris awal terhadap kepercayaan Marapu pada dasarnya negatif. Kepercayaan Marapu dilihat sebagai suatu bentuk penyembahan berhala dan kekafiran. Pewartaan Injil bertujuan menghapus kekafiran itu dan menggantinya dengan kekristenan. Karena itu para misionaris

\footnotetext{
${ }^{5}$ Herman P. Panda, "Usaha Penyesuaian Liturgi dalam Budaya Sumba dan Konteks Kepercayaan Marapu", dalam Bernardus Boli Ujan dan G. Kirchberger (eds.), Liturgi Autentik dan Relevan (Maumere: Ledalero, 2006), hlm. 155 .
}

awal berjuang membaptis orang sebanyak mungkin sebab "kolektif kafir hanya dapat diatasi dengan suatu kolektif baru". ${ }^{6}$

Pandangan seperti ini berlangsung selama bertahun-tahun. Para pelayan Gereja baik Katolik maupun Protestan menuntut pertobatan total dari orang-orang Sumba yang beralih ke agama kristen. Mereka misalnya melarang dengan tegas orang-orang yang telah dibaptis mengambil bagian dalam upacara Marapu. Dalam rangka pertobatan total itu, tidak jarang pula benda-benda yang dianggap sakral dalam kepercayaan Магари harus dimusnahkan bila orang berpindah ke agama kristen. Dan untuk menegaskan kepada orang-orang Sumba yang telah menjadi kristen perbedaan antara kekristenan sebagai agama yang benar dan Marapu sebagai kekafiran, bahkan Marapu disamakan dengan setan. Demikian pun penyembahan kepada Marapu disebut dosa berat. Baru setelah diprotes oleh orang-orang Магари, mulai dibedakan antara Marapu baik (arwah leluhur, roh pelindung suku) dari Marapu jahat seperti roh penghuni padang dan hutan. ${ }^{7}$

Setelah Konsili Vatikan II, mulai ada pandangan yang lebih positif terhadap Marapu. Minat untuk mempelajari kepercayaan Marapu di antara para pelayan Gereja memang belum banyak tetapi telah terdapat beberapa pemula. Anita Nudu (1983) berusaha

\footnotetext{
${ }^{6}$ Anita M. Ningga Nudu, "Iman Kristiani dan Marapu" dalam Kaleidoskop Gereja Katolik Sumba dan Sumbawa 1889-1989, (Weetebula: 1989), hlm. 95.

${ }^{7}$ J. Hoskins, The Play of Time, Kodi Perspectives on Calendars, History and Exchange (Los Angeles - London: 1993), hlm. 272.
} 
menemukan perjumpaan antara iman akan Yesus Kristus dan kepercayaan Marapu. Nudu berpendapat bahwa leluhur (Marapu) patut diterima dan digabungkan dalam pengantaraan tunggal Yesus Kristus. ${ }^{8}$ Edmund Woga (2004) juga berbicara tentang dialog antara agama asli Sumba dan kekristenan. Woga berbicara tentang titik temu antara "teologi asli" Sumba dan teologi kristen. ${ }^{9}$ Dari studi mereka telah diangkat beberapa kesejajaran antara kepercayaan Marapu dan kekristenan sehingga pewartaan agama kristen sebenarnya hanya melengkapi apa yang belum ada dalam kepercayaan Marapu. ${ }^{10}$

Di lingkungan protestan terdapat juga percobaan perjumpaan antara doktrin implisit dalam Marapu dan teologi kristen. Dalam sinode GKS tahun 1984 didiskusikan kesejajaran antara teologi kristen dan doktrin Marapu. ${ }^{11}$ Yang banyak diangkat adalah kesejajaran antara peristiwa-peristiwa Perjanjian Lama dan peristiwa-peristiwa ritual Marapu.

\section{Komunitas Kampung Adat Dan Komunitas Gerejawi}

Masyarakat Sumba terdiri atas rumpunrumpun keluarga yang disebut kabizu (clan). Anggota-anggota suatu clan

${ }^{8}$ Anita M. Ningga, Pertemuan Marapu dengan Yesus Kristus (Skripsi) (Yogyakarta: IKIP Santha Dharma, 1983), hlm. 20.

${ }^{9}$ Edmund Woga, Der Parentale Gott: Zum Dialog zwischen der Religion der indonesischen Völker Sumbas und dem Christentum (Nettetal: Seyler Verlag, 1994), hlm. 315-373.

10 Anita M. Ningga Nudu, "Iman Kristiani”, Op. Cit., hlm. 98.

${ }^{11} \mathrm{~J}$. Hoskins, The Play, Op. Cit., hlm. 300 . walaupun tersebar di mana-mana bahkan di luar Sumba tetapi memiliki ikatan yang kuat. Setiap clan terdiri atas sejumlah sub-clan (uma). Tiap-tiap uma memiliki uma kalada (rumah besar) di wano kalada (kampung besar).

Ikatan dalam satu clan dirakit erat oleh devosi pada Marapu yang sama yang disebut Marapu uma (Marapu rumah) dengan berbagai ritual. Магари uта menunjuk leluhur bersama komunitas clanyang merupakan tujuan devosi. Selain itu, setiap peristiwa penting dalam hidup manusia tidak dipisahkan dari relasi dengan Marapu, sehingga selalu disertai dengan ritual tertentu. Peristiwa atau hajatan tersebut melibatkan anggota-anggota kabizu baik yang Marapu maupun yang Katolik. Ada sejumlah peristiwa yang melibatkan seluruh anggota kabizu, antara lain pembangunan uma kalada (rumah adat), pemakaman seorang anggota keluarga yang meninggal, perkawinan, upacara pemujaan besar pada Marapu yang disebut zaigho dan gholeka. Pusat dari seluruh pemujaan Marapu adalah wano kalada (kampung besar). Komunitas kabizu boleh dikatakan adalah komunitas kampung besar.

Karena sebagian besar orang Sumba menjadi Kristen, mereka merupakan pula warga dari komunitas gerejawi yang terbentuk. Komunitas gerejawi dengan strukturnya dari tingkat komunitas basis, lingkungan, stasi, paroki merupakan pusat-pusat baru kegiatan keagamaan bahkan pula kegiatan kemasyarakatan bagi orang Sumba. Orang-orang Katolik adalah warga komunitas gerejawi, tetapi pada saat yang sama mereka tidak dapat melepaskan kewargaannya dalam kabizu, termasuk tuntutan keterlibatan dalam kegiatan komunitas kabizu. 
Kewargaan ganda dari orang-orang Katolik kadang-kadang menimbulkan suatu tumpang tindih yang terjadi baik pada level iman / kepercayaan maupun ritual keagamaan. Pada level iman, terjadi dualitas yaitu percaya pada Tuhan yang diwartakan Gereja, sekaligus percaya pula pada Marapu. Bahkan beberapa figur dalam iman Katolik diidentikkan secara spontan dengan beberapa Marapu yang telah menjadi tujuan pemujaan mereka. ${ }^{12}$ Pada level ritual, terjadi praktek ganda. Selain ibadat dan doa Katolik, juga beberapa ritual Marapu tetap dipraktekkan.

Praktek ganda seperti itu terutama berkaitan erat dengan peristiwa-peristiwa penting dalam hidup manusia. Ketika seseorang mengalami sakit parah misalnya, selain diusahakan pengobatannya, juga didoakan secara Katolik antara lain dengan sakramen pengurapan orang sakit. Selain itu diadakan pula ritual Marapu untuk mencari penyebab sakit tersebut di dunia supernatural. Usaha yang disebut terakhir ini memiliki konsekwensi lebih lanjut yaitu pelaksanaan sejumlah ritual yang dituntut Marapu, sebagaimana yang dilihat oleh pemimpin ritual berdasarkan penafsirannya atas hati binatang kurban. Banyak peristiwa hidup lain yang dijalankan menurut upacara Katolik dan adat Sumba seperti perkawinan dan pemakaman. Dan dalam pelaksanaan tatacara adat tersebut terdapat penyelipan sejumlah unsur ritual Marapu.

${ }^{12}$ Herman P. Panda, "Mengapa Orang Katolik Masih Menjalankan Ritual Marapu? Menguak Praktik Iman Ganda di Loura" dalam Jurnal Ledalero, Vol. 13, No. 1, Juni 2014.

\section{Pandangan atas derita dan kemalangan}

Dalam pandangan para penganut Marapu, derita dan kemalangan yang menimpa manusia pada dasarnya dilihat sebagai akibat kemarahan Marapu atau roh yang menghuni setiap sudut alam, karena dosa dan kelalaian manusia. Kematian mendadak misalnya akibat kecelakaan lalu lintas apa lagi kalau terjadi secara berturut-turut menimpa anggota-anggota dari satu kabizu selalu dikaitkan dengan kemarahan Marapu. Biasanya setelah kematian mendadak tersebut dengan segera dipanggil pemimpin ritual Marapu untuk mencari penyebabnya melalui ritual tertentu. Setelah penyebabnya diketahui, selanjutnya diadakan upacara penyilihan dosa supaya terhindar dari bahaya selanjutnya. Dalam penelitian kami, dalam kurun waktu lima tahun terdapat empat kasus orang Katolik yang mati karena kecelakaan lalu lintas dan masing-masing diupacarakan menurut kepercayaan Marapu dalam kurun waktu setahun - dua tahun setelah dimakamkan menurut upacara Katolik.

\section{Problem penerjemahan konsep- konsep religius \\ Dalam penelitiannya, Hoskins sudah mengamati sulitnya menerjemahkan konsep-konsep teologis kristen ke dalam ungkapan yang sepadan dalam Marapu atau sebaliknya konsep- konsep religius dalam Marapu ke dalam kekristenan. Hoskin menulis: "Translating Sumbanese religious concepts was a challenging task because of the very different semantic weights assigned to words in the two systems". ${ }^{13}$}

${ }^{13}$ J. Hoskins, The Play, Op. Cit., hlm. 293. 
Apa yang diamati Hoskins di atas telah nyata dalam pengalaman para misionaris yang mencoba menerjemahkan istila atau konsep kristen ke dalam Bahasa daerah Sumba. Persoalan utama adalah tidak tersedianya istila sepadan yang siap pakai dalam khazanah Bahasa daerah Sumba untuk istila-istila teologi Kristen. Misalnya, dalam khazanah religiositas asli orang Sumba tidak dikenal adanya Kitab Suci. Ketika kata Kitab Suci diterjemahkan dalam Bahasa Sumba, harus diciptakan istila atau gabungan kata yang bagi orang Sumba sendiri tetap baru dan asing. Kata Kitab suci misalnya diterjemahkan dalam dialek kambera (Sumba Timur) dengan Huratu bokulu (surat besar) atau Huratu matua (surat suci). ${ }^{14}$

Kesulitan yang sama terjadi pula dalam usaha menerjemahkan nama Allah Pencipta, Yesus Kristus dan Roh Kudus ke dalam Bahasa Sumba. Untuk nama Allah Pencipta, memang dikenal Ina Magholo - Ama Marawi (Ibu dan Bapak Pencipta) namun ketika digunakan dalam kekristenan untuk menunjuk Allah Pencipta langit dan Bumi, Bapak Tuhan Yesus Kristus masih dibutuhkan penjelasan tambahan. Bila tidak, orang Sumba akan tetap pada konsep lama mereka dalam kepercayaan Marapu tentang Pencipta. Lambooij pernah mengusulkan agar nama Allah diterjemahkan dengan Marapu, yaitu nama yang ilahi yang telah dikenal oleh orang Sumba. ${ }^{15}$ Namun sebagaimana dikritik oleh Wielenga, ${ }^{16}$ hal ini amat tidak tepat karena Marapu menunjuk roh-roh, juga arwah leluhur yang

\footnotetext{
${ }^{14}$ F.D.Wellem, Op. Cit., hlm. 292

${ }^{15}$ Ibid., hlm. 301.

${ }^{16}$ Ibid.
}

jumlahnya banyak. Hal yang lebih sulit lagi adalah menjelaskan siapa Yesus Kristus Putera Allah atau Roh Kudus supaya dipahami oleh orang Sumba. Ada yang mengusulkan bahwa Yesus Kristus dapat disebut Marapu sejati karena Kristus adalah pengantara tunggal antara Allah dan manusia sebagaimana Marapu merupakan pengantara antara Sang Pencipta dan manusia. ${ }^{17}$ Hal ini pun masih perlu penjelasan atas perbedaan antara Kristus dan para Marapu walaupun ada kesejajaran dalam fungsi pengantaraan.

\section{Prinsip-prinsip perjumpaan}

Usaha mencari kesejajaran dan titik temu antara kekristenan dan Marapu memang tidak mudah karena keduanya berada pada tataran yang berbeda. Menurut A. Pieris, agamaagama dibedakan antara agama kosmik yang meliputi berbagai kepercayaan asli dan metakosmik yang meliputi agamaagama besar seperti Kristen, Islam, Hindu dan Buddha. ${ }^{18}$ Mengikuti pandangan tersebut Marapu tergolong dalam kelompok agama-agama kosmik. Di antara kedua jenis agama tersebut di atas kadang-kadang terdapat sejumlah pandangan yang secara ekstrim berbeda satu sama lain. Untuk itu dibutuhkan beberapa prinsip dalam usaha perjumpaan:

\footnotetext{
${ }^{17}$ Ibid., hlm. 311.

${ }^{18}$ Pieris, "Interreligious Dialogue and Theology of Religions: An Asian Paradigm", dalam East Asian Pastoral Review 29 (1992), 365-376, hlm. 367.
} 
Mempertahankan keotentikan sambil saling transformasi

Usaha perjumpaan antara teologi kristen dan kebudayaan-kebudayaan setempat pada dasarnya harus menghindari bahaya reduksi atas iman kristen. Dalam hal ini inti wahyu dan doktrin iman yang bernilai abadi harus masuk secara utuh ke dalam kebudayaan setempat dan tidak boleh dikurangi agar cocok dengan kebudayaan yang menerimanya. Dalam usaha ini perlu dibedakan sungguh-sungguh dua hal pokok yang saling berkaitan erat satu sama lain yaitu relativitas perumusan dan kemutlakan kebenaran iman dan pesan wahyu kristen. Perumusan suatu teks baik Kitab Suci maupun teks dogmatis terkondisi oleh konteks budaya, bahasa, politik dan ideologi yang berkembang pada tempat dan zaman ketika teks itu muncul. Sedangkan isi pesan wahyu dan kebenaran iman yang ingin diungkapkan bersifat abadi dan dapat berlaku di segala tempat, zaman dan konteks situasi. Kebenaran iman seperti itu yang kini berjumpa lagi dengan konteks situasi yang baru.

Usaha yang benar dalam teologi inkulturasi adalah penerimaan isi iman dan pesan wahyu Kristen secara utuh dalam kebudayaan dan religiositas setempat. Nilai-nilai yang terdapat dalam kebudayaan setempat yang tidak bertentangan dengan isi iman kristen dibiarkan tetap utuh, dipelihara, dipertahankan dan diterima untuk memperkaya kekristenan. Sebaliknya, isi wahyu dan doktrin iman serta nilai-nilai baik lain dari kekristenan yang belum dimiliki oleh kebudayaan setempat itu diwartakan untuk memperkaya bahkan mengoreksi kebudayaan setempat.
Melalui teologi inkulturasi terjadi saling transformasi timbal-balik antara kekristenan dan kebudayaan setempat. Dalam hal ini bukan hanya kebudayaan setempat yang ditransformasikan melainkan juga kekristenan. Kekristenan ketika masuk ke dalam kebudayaan baru, dapat dibebaskan dari bias-bias kebudayaan lama yang juga belum sempurna yang telah lama menyertai kekristenan itu. Dengan demikian dihasilkan suatu kekristenan yang dibaharui sesuai konteks kebudayaan setempat, sambil tidak dikurangi keutuhannya dan pada saat yang sama mentrasformasikan kebudayaan setempat menuju keadaan yang lebih baik.

\section{Perjumpaan pada lapisan kebudayaan yang lebih dalam}

Sejumlah ahli memahami kebudayaan itu terdiri atas lapisanlapisan dari yang kelihatan sampai ke bagian yang lebih dalam yang membingkai semua yang kelihatan itu. Barney (1973) dalam Hesselgrave dan Rommen (1989) mengemukakan model kebudayaan dengan lapisan luar berupa perilaku dan kebiasaan-kebiasaan yang bisa diamati, menyusul pranata-pranata, nilai-nilai dan akhirnya ideologi, kosmologi dan pandangan dunia. ${ }^{19}$ Nchols (1979) mengaplikasikan model kebudayaan Barney ini dalam kontekstualisasi. Menurutnya kontekstualisasi terjadi pada tingkatan dogmatik. $^{20}$ Mantovani (1996) dengan cara yang mirip membedakan antara hal yang universal sebagai "akar" dan

\footnotetext{
${ }^{19}$ D.J. Hesselgrave dan Edward Rommen, Kontekstualisasi: Makna, Metode dan Model, Terjemahan Stephen Suleeman (Jakarta: BPK Gunung Mulia, 2004), hlm. 74.

${ }^{20}$ Ibid., hlm. 76.
} 
pengejawantahan kultural sebagai "daun". Dan dalam kontekstualisasi orang harus menerima "akar" itu sambil menggunakan "daun" kulturalnya sendiri. $^{21}$

Titik temu antara iman dan kebudayaan pertama-tama terjadi pada tingkatan doktrinal atau hal-hal yang berlaku universal ("akar") dan kemudian pada tingkatan yang kelihatan dan khas bagi tiap-tiap kebudayaan (“daun"). Pada tingkatan pertama, perjumpaan terjadi antara isi iman kristen dan nilai-nilai kebudayaan setempat. Pada tingkatan kedua perjumpaan terjadi pada lapisan yang kelihatan seperti ritual, bendabenda simbolis dan ungkapan-ungkapan verbal. Mantovani (1996) mengusulkan suatu analisis kebudayaan yang berusaha menemukan nilai-nilai budaya setempat yang sama dengan tema-tema biblis dan teologis walaupun cara pengejawantahannya berbeda. Tematema yang universal dan biblis itu antara lain: kasih, pengampunan, syukur, saling menghormati, kepercayaan dan ketergantungan total pada Allah. Hal-hal yang baru dalam kekristenan seperti "Kematian Yesus Kristus di salib sebagai peragaan kasih Bapak" dapat menantang kebudayaan setempat dan mentransformasikannya menuju kesempurnaan dalam praktek kasih yang tanpa batas.

Analisis atas fenomen kebudayaan bertujuan menemukan nilai-nilai kebudayaan itu. Setelah menemukan nilai-nilai kebudayaan, akan jelas apakah nilai itu sama atau bertentangan dengan

\footnotetext{
${ }^{21}$ Ennio Mantovani, "Antara Tatanan Nilai dengan Etika Kristen dan Merlanesia: sebuah Dialog", dalam Kirchberger, G. dan John M. Prior (eds.) Iman dan Transformasi Budaya (Ende: Nusa Indah, 1996), hlm. 233.
}

pesan wahyu dan ajaran iman kristen. Bila sama, nilai itu diangkat dan diintegrasikan ke dalam iman Katolik, termasuk peragaannya yang bersifat lokal. Hal ini sejalan dengan anjuran Paus Yohanes Paulus II, supaya Gereja "mengambil unsur-unsur baik yang ada dalam kebudayaan-kebudayaan itu dan memperbaharuinya dari dalam". ${ }^{22}$

\section{Menuju konstruksi Teologi kematian dalam konteks budaya Sumba}

Teologi tentang kematian adalah teologi tentang akhir hidup manusia individual di dunia ini. Eskatologi ini dibedakan dari eskatologi final yaitu tentang akhir zaman. Di bawah ini adalah suatu usaha mencari titik temu antara doktrin implisit tentang kematian yang terdapat dalam tradisi oral penganut Marapu dan doktrin Katolik tentang hidup sesudah kematian. Ada sejumlah titik temu antara keduanya walaupun ada pula sejumlah hal yang amat berbeda satu sama lain. Seperti dikemukakan dalam prinsip perjumpaan di atas, akan diselidiki tema-tema yang berlaku universal baik yang terdapat dalam kepercayaan Marapu maupun dalam ajaran iman Katolik di sekitar konsep tentang kematian walaupun cara pengungkapannya berbeda. Tetapi sebelumnya akan diuraikan terlebih dahulu secara ringkas konsep kematian dalam kepercayaan Marapu.

22 Paus Yohanes Paulus II, Redemptoris Missio, Ensiklik (7 Desember 1990), Terjemahan Marcel Beding (Ende: Nusa Indah, 1992), no. 52. 
Kematian sebagai perjalanan Dewa (jiwa) ke Wano Marapu (Kampung leluhur)

Kematian adalah peristiwa lepasnya dewa (jiwa / unsur yang berlangsung hidup setelah kematian) dari tou (tubuh). Setelah lepas dari tubuh, jiwa manusia memulai perjalanan ke wano Marapu (kampung leluhur) yaitu tempat peristirahatan terakhir jiwa-jiwa orang yang telah meninggal. Namun untuk tiba di wano Marapu tersebut, jiwa menempu proses yang bertahaptahap. Anggota kabizu yang masih hidup berperanan penting untuk panuduni lara (menuntun di jalan) artinya mengorientasikan jiwa orang mati itu melalui berbagai ritual, agar dapat tamana wano - padina natara (memasuki kampung dan berjalan di pelataran kampung Marapu).

Wano Marapu yaitu tempat peristirahatan terakhir jiwa-jiwa itu menurut penuturan beberapa informan kami, berada di Tanjung Sasar, di ujung Utara pulau Sumba. Tanjung Sasar diyakini sebagai tempat leluhur pertama kali mendarat di pulau Sumba ketika datang dari seberang laut dan di sana mereka membangun perkampungan. Perkampungan asli dan pertama itu tidak kelihatan lagi sekarang, tetapi dipercaya ada dan merupakan tempat berkumpul kembali jiwa-jiwa orang Sumba setelah meninggal. Walaupun Tanjung Sasar itu tempat yang nyata di Bumi, tetapi dalam pemahaman para penganut Marapu, tidak sekadar duniawi. Perkampungan jiwa-jiwa orang mati itu diyakini sungguh nyata tetapi tidak kasat mata dan merupakan tempat perjumpaan antara Yang Ilahi dan manusiawi, tempat persekutuan abadi jiwa-jiwa manusia dengan para Marapu besar. Hal ini dapat dibandingkan dengan pandangan orang
Sumba tentang roh-roh yang hadir di padang (Marapu tana), di hutan (Marapu kadaghu), di laut (Marapu bопи) dan lain-lain, yang diyakini hidup dalam komunitas perkampungan seperti manusia tetapi tidak kasat mata.

Wano Marapu dipahami sebagai situasi yang serba baru dan tidak berkekurangan, walaupun masih ada kesamaannya dengan kehidupan manusia di alam nyata. Para jiwa di sana juga hidup berpasang-pasangan sebagai suami istri, memerlukan harta, melaksanakan usaha seperti berkebun dan memelihara ternak. Demikian pula perbedaan klas sosial tetap berlaku, di mana ada bangsawan dan ada hamba. ${ }^{23}$ Jiwa-jiwa mulia yang telah diam di wano Marapu hidup seperti Marapu yaitu dapat pulang dan pergi dari perkampungan Marapu ke perkampungan manusia di dunia nyata.

Kematian merupakan awal perjalanan jiwa menuju wano Marapu. Keadaan jiwa setelah lepas dari tubuh, diyakini bebas berkeliaran di sekitar rumah dan di rumah-rumah anggota keluarga terutama di rumah loka (saudara laki-laki ibu). Rumah loka merupakan mata wee - pu'u ghazu (sumber air - pangkal pohon), artinya tempat asal kehidupan. Karena itu, ketika jiwa lepas dari tubuh dia kembali ke tempat asalnya yaitu di rumah loka. Namun bukan di sanalah tempat peristirahatan terakhir jiwa itu melainkan harus tiba di wano Marapu. Untuk itu jiwa tersebut diorientasikan melalui sejumlah ritual dan doa.

\footnotetext{
${ }^{23}$ G.L. Forth, "Rindi, an Ethnographic Study of a Traditional Domain in Eastern Sumba", dalam Verhandelingen van het Koninklijk Instituut voor Taal-, Land en Volkenkunde 93 (The Hague: 1981), hlm. 200.
} 
Ritual dan doa sudah dimulai pada saat kematian. Doa tidak ditujukan langsung kepada Magholo marawi (Sang Pencipta) melainkan kepada para Marapu dengan perantaraan para leluhur. Para Marapu itulah yang selanjutnya menyampaikan doa-doa manusia kepada Sang Pencipta. Jadi dibutuhkan serangkaian pengantara secara keseluruhan ${ }^{24}$ sebelum tiba kepada Sang Pencipta.

Pada hari penguburan disiapkan bekal yang dibawa oleh orang yang meninggal berupa makanan, minuman, alat memasak, beras, gabah, kelapa muda, kelapa tua, ubi, pisang dan ayam dalam sangkar. Semua bekal yang disiapkan diserahkan kepada jiwa orang mati itu dalam doa pada malam menjelang penguburan. Semua bekal itu kemudian diambil oleh loka, tetapi dipercaya bahwa "jiwa" dari bekal itu dibawa oleh jiwa orang yang meninggal. Hal yang sama berlaku pula dalam pemberian makanan kepada jenazah sebanyak tiga kali sehari selama masih disemayamkan di rumah sebelum penguburan. Makanan ketika diayunkan sebanyak tiga kali di depan mulut jenazah dipercaya bahwa "jiwa" makanan telah dimakan oleh orang mati sedangkan "badan" makanan itu kemudian dibuang di luar rumah. Demikian juga "jiwa" semua hewan yang disembeli pada waktu penguburan akan diambil oleh arwah-arwah para kerabat yang telah mati yang juga hadir pada waktu penguburan, sedangkan "badan" (daging) binatang itu dibagibagikan kepada undangan yang hadir pada hari penguburan. Penyebaran beras pada waktu jenazah diusung ke tempat pemakaman juga bermakna pemberian

${ }^{24}$ J. Hoskins, The Play, Op. Cit., hlm. 279. makanan kepada semua arwah kerabat yang hadir.

Selain dewa yang lepas dari tubuh, terdapat pula magho (naungan atau bayangan) yaitu kewibawaan, kekuatan dan pengaruh dari orang yang meninggal. Magho dalam arti seperti ini akan keluar juga dari tubuh bersamaan dengan hancurnya tubuh itu. Karena itu, magho perlu diwariskan kepada anak cucunya. Dengan kata lain kekuatan, pengaruh dan kewibawaan dari orang yang meninggal (terutama yang sudah berusia lanjut) perlu dibagi-bagikan kepada anak cucunya. Untuk itu menurut tradisi, yang mendapat kehormatan menerima bagian dari magho itu adalah para saudari dan anak perempuan dari yang meninggal. Hal inilah yang dilaksanakan melalui peristiwa kouta magho (mengangkat magho) sebelum pintu makam ditutup setelah jenazah dimasukkan ke dalam makam. Jalannya upacara: sejumlah kain tenunan tangan diletakkan di atas makam sebanyak jumlah dari anak-anak perempuan atau saudari dari yang meninggal, selanjutnya anak-anak perempuan itu mengambil kain-kain itu satu persatu untuk dibawa pulang.

Selain itu, jiwa yang lepas dari tubuh diyakini mengalami kelahiran baru. Hal ini nyata dalam penyiapan peralatan bayi seperti kaleraka (alas tidur / buaian bayi), seekor ayam dan sebuah kelapa tua yang juga biasa dipakai dalam ritual pemberian nama bayi yang baru lahir, dan hati kerbau yang diletakkan di atas makam sebagai simbol dari plasenta. Jiwa itu memasuki kembali periode seperti bayi yang tidak berdaya dan amat membutuhkan tuntunan dan bantuan manusia.

Dari uraian di atas, tampak bahwa pandangan atas jiwa dan perjalanannya 
menuju wano Marapu terkesan masih bersifat manusiawi atau duniawi. Jiwa masih membutuhkan bekal dan harta kekayaan untuk hidup baru di alam baka. Demikian juga gambaran tentang wano Marapu. Wano Marapu, tempat peristirahatan terakhir jiwa-jiwa, sejajar dengan wano Kalada tempat berhimpun komunitas manusia dalam ikatan kabizu (clan). Gambaran wano Kalada duniawi dengan pelataran dikenakan pula untuk tempat peristirahatan terakhir jiwa-jiwa dalam persekutuan dengan para leluhur dan para Marapu di hadapan Sang Pencipta. Selanjutnya terdapat hubungan mistik antara wano kalada duniawi dan wano Marapu di alam baka. Hubungan itu dijalin berkat adanya arwah leluhur yang telah selamat di wano Marapu. Jiwa-jiwa bahagia itu seperti para Marapu dapat "datang dan pergi" (dikita noneka) dari wano Marapu di alam bakake dunia nyata. Mereka dapat mendatangkan a maringi - a malalana (yang sejuk dan segar) yaitu kemakmuran, kesejahteraan dan keselamatan bagi manusia yang hidup. Mereka dapat pula mendatangkan hukuman bila manusia melakukan pelanggaran moral atau pelanggaran tata cara adat.

Baik di dalam rumah-rumah adat suku (uma kalada) maupun pelataran kampung adat terdapat banyak tagu Marapu (tempat bersemayam para Marapu dan arwah leluhur). Karena itu pemujaan Marapu sehari-hari terdiri dari pemberian persembahan makanan kepada para Marapu dan arwah leluhur yang diyakini "datang dan pergi" dari wano Marapu di alam baka ke dunia nyata dalam komunitas kampung adat. Status jiwa yang baru lepas dari tubuh takkan mencapai wano Marapu jika manusia yang hidup (anggota kabizu) tidak melakukan sejumlah ritual. Bila sejumlah ritual pemakaman belum tuntas dilaksanakan tetapi hanya berupa pemakaman sementara, jiwa-jiwa orang mati masih berkeliaran di sekitar rumah dan belum memulai perjalanan menuju ke wano Marapu. Jiwa-jiwa seperti ini dapat mengganggu ketenteraman manusia yaitu mendatangkan sakit, nasib sial bahkan kematian bila tidak segera dituntaskan upacara pemakaman mereka. Pada dasarnya jiwa-jiwa seperti itu tidak berkarakter jahat, tetapi mereka menuntut supaya manusia yang hidup menjalankan tanggungjawabnya menuntaskan segala ritual demi keselamatan jiwa-jiwa itu.

Manusia berkewajiban menjalankan upacara pemakaman yang tuntas pertama-tama tentu karena kasih sayang dan hormat kepada orang yang meninggal, supaya dia dapat tiba di wano Marapu. Bila tidak cukup biaya untuk melakukan pemakaman yang tuntas, orang yang meninggal dapat dimakamkan dengan tata cara pemakaman sementara sambil manusia (anggota keluarga yang masih hidup) berjanji kepada arwahnya dan kepada Marapu bahwa pada suatu saat nanti dia akan dimakamkan dengan upacara tuntas. Selain itu dimohonkan pula kemurahan para Marapu untuk mendatangkan rejeki bagi orang yang hidup agar dapat segera melaksanakan janji yaitu pemakaman yang tuntas. Tetapi janji itu bila lama tidak dilaksanakan, Marapu akan menuntut dengan mendatangkan mala petaka bagi keluarga dari orang yang meninggal. Hal ini pula yang menimbulkan ketakutan bagi penganut Marapu sehingga mau tidak mau menjalankan tata cara pemakaman yang tuntas meskipun mahal. 
Memang kepercayaan Marapu mengakui pula bahwa manusia secara kodrati harus mati bila mencapai usia tua, tetapi terdapat jenis kematian yang dipahami sebagai akibat hukuman Marapu. Marapu mendatangkan hukuman bagi manusia atas kelalaian dan dosa-dosa manusia. Dosa dan kelalaian yang bisa mengakibatkan kematian itu meliputi pelanggaran moral terutama dosa hubungan sumbang (incest), kelalaian melaksanakan li'i (nazar) dari leluhur, kelalaian melaksanakan kewajiban menuntaskan pemakaman anggota keluarga yang telah meninggal dan profanasi atas barang-barang yang dikhususkan untuk Marapu.

Dosa dan pelanggaran tata cara adat selalu memiliki akibat bagi seluruh anggota uma (sub-clan). Karena itu kematian secara tidak wajar yang menimpa seseorang seringkali bukan akibat dari pelanggaran moral orang yang mati itu sendiri melainkan oleh anggota uma yang lain. Hal ini paling nyata dalam kasus kematian seorang anak kecil atau bayi yang belum dapat membedakan yang baik dan yang jahat.

\section{Refleksi anthropologis}

Analisis ini hendak mengemukakan nilai-nilai yang terungkap dari sikap dan tindakan yang dilaksanakan pada saat seorang anggota keluarga mengalami kematian. Sikap dan tindakan tersebut pertama-tama dipahami dan dinilai berdasarkan tatanan budaya orang-orang Sumba sendiri. Ada tiga tema yang dapat diringkas dari uraian atas konsep kematian sebagai perjalanan jiwa menuju "kampung leluhur". Tema pertama, kepercayaan akan adanya "komunitas kampung leluhur" tempat para arwah hidup dalam persekutuan dengan para marapu yang merupakan cerminan dari komunitas kampung besar, tempat persekutuan anggota-anggota kabizu yang masih hidup. Tema kedua, proses perjalanan jiwa menuju kampung leluhur. Tema ketiga, peranan orang hidup dalam mengorientasikan jiwa menuju ke "kampung leluhur". Terdapat tatanan nilai yang menghubungkan ketiga tema tersebut.

Nilai kunci diungkapkan dalam bahasa Sumba maringina - malalana (sejuk dan segar) yang memiliki makna sejahtera, selamat, damai, harmoni, tenteram, keberuntungan. Untuk mudahnya kita sebut saja hidup yang sejahtera. Hidup yang demikian bersifat menyeluruh dan mempengaruhi segala aspek kehidupan manusia. ${ }^{25}$ Dan hal ini erat kaitannya dengan konsep religiositas kosmik yang dapat diterapkan pula pada agama Marapu, yaitu religiositas yang bercorak "kini di dunia ini."26 Hidup yang sejahtera itu bersifat kosmik dan mempengaruhi seluruh kosmos.

Hidup sejahtera juga dikaitkan dengan relasi yang harmonis dan lancar yang para ahli anthropologi ungkapkan sebagai pengaliran kehidupan. ${ }^{27}$ Relasi yang mengalirkan kehidupan itu menyangkut baik relasi horizontal yaitu relasi sosial antar manusia dan relasi dengan segala unsur alam lain maupun relasi vertikal yaitu relasi mistik dengan para leluhur, Marapu dan Sang Pencipta.

${ }^{25}$ Ennio Mantovani, Op.Cit., hlm. 219.

${ }^{26} \mathrm{~A}$. Pieris, "Interreligious Dialogue and Theology of Religions: An Asian Paradigm", dalam East Asian Pastoral Review 29 (1992), 365-376, hlm. 369.

${ }^{27}$ Ennio Mantovani, Op. Cit., hlm. 219; lihat juga J. M. Prior, Bejana Tanah Nan Indah: Refleksi Sosio-Budaya atas Jemaat-Jemaat Basis Nusa Tenggara Sebagai Wujud Evangelisasi Baru (Ende: Nusa Indah, 1993), hlm. 81. 
Relasi sosial di antara manusia dan relasi manusia dengan segala unsur alam dipelihara dan dipertahankan melalui kerjasama dan pertukaran hadiah. Relasi kekerabatan kunci meliputi relasi antara seseorang dan pamannya (saudara ibu) serta relasi di antara seorang wanita (terutama yang sudah berkeluarga) dan saudara lakilakinya. Kedua pihak ini (saudara lakilaki ibu dan saudara laki-laki istri) merupakan pemberi wanita bagi clan ego dan wanita yang diberikan itu akan melahirkan generasi baru bagi clan tersebut. Karena itu keduanya disebut mata wee - pu'u ghazu (sumber air pangkal pohon) yaitu sumber dari mana kehidupan mengalir. Relasi ini dilestarikan melalui pertukaran hadiah dan perkawinan. Biasanya pihak pengambil wanita memberikan hadiah berupa hewan besar seperti kerbau atau kuda sedangkan pihak pemberi wanita memberi kain tenun dan babi. Secara tradisional, perkawinan seorang laki-laki dengan anak pamannya dianggap baik karena memperbaharui relasi dengan sumber dan pangkal hidup.

Relasi yang harmonis di antara manusia dan dengan segala unsur alam merupakan persyaratan bagi hidup yang sejahtera. Relasi itu terutama menyangkut relasi kunci kekerabatan di mana terjadi pengaliran kehidupan: dari seorang laki-laki kepada saudarinya dan anak-anak saudarinya. Lebih lanjut, karena saudari dan anak-anak saudari dari seorang laki-laki telah menjadi anggota clan lain (mengikuti clan suami atau ayah mereka), aliran kehidupan itu berjalan dari satu clan ke clan lain.

Pada saat pemakaman seseorang, relasi aliran kehidupan itu diragakan melalui upacara kouta magho (mengangkat spirit) sebelum makam ditutup.
Kehidupan dialirkan dari orang yang mati ke pihak saudari dan anak-anak puterinya, melalui tindakan simbolis, yaitu setiap saudari dan anak puteri mengangkat selembar kain dari atas makam. Magho dipahami sebagai pengaruh baik, kewibawaan, keberuntungan yang dibagi-bagikan kepada saudari dan anak puteri yang telah berpindah ke clan lain mengikuti suami mereka. Dengan itu "yang sejuk dan segar" dialirkan ke clan lain dari pihak "sumber air - pangkal pohon" yaitu orang yang meninggal. Dengan demikian, pengaliran kehidupan berlangsung tanpa batas, mengikuti setiap saudari atau anak puteri yang berpindah ke clan lain karena perkawinan.

Penyaluran hidup melalui proses penurunan anak-anak oleh orangtua dalam pandangan orang Sumba bersifat garis lurus melalui clan ayah dan garis menyamping melalui clan asal ibu (clan Paman). Clan ayah disebut uma katonga (rumah - balai-balai) artinya tempat hidup dan bertumbuhnya kehidupan sedangkan clan Paman disebut "sumber air - pangkal pohon", sumber dari mana kehidupan mengalir. Pada gilirannya, clan ayah juga merupakan "sumber air - pangkal pohon" bagi saudari ayah (dan anakanaknya) yang sudah keluar dari clan ayah dan madi'ina uma - katonga (menduduki rumah dan balai-balai) sendiri yaitu clan suami.

Relasi mistik antara manusia yang hidup dengan para leluhur, Marapu dan Sang Pencipta boleh dikatakan relasi yang bersifat vertikal. Dalam pandangan orang Sumba terdapat relasi mistik antara kampung besar duniawi tempat berlangsungnya kehidupan sosial anggota-anggota kabizu dan kampung 
para leluhur tempat peristirahatan terakhir jiwa-jiwa orang mati bersama para Marapu dan Sang Pencipta. Relasi seperti ini dijaga dengan cermat supaya tetap berjalan harmonis sehingga tetap mengalir a maringi - a malalana (yang sejuk dan segar). Kampung besar Marapu merupakan sumber mengalirnya yang sejuk dan segar kepada manusia. Tersendatnya atau terganggunya relasi akibat dosa dan kelalaian manusia mengakibatkan derita dan kemalangan manusia sebab tidak lagi mengalir lancar yang sejuk dan segar itu.

Segala ritual dan doa pada saat orang meninggal sampai pada penguburannya bertujuan untuk panuduni lara (menunjukkan jalan), yaitu mengorientasikan jiwa itu supaya dapat tiba di kampung besar Marapu. Usaha ini pun berkaitan dengan relasi antara manusia dan para Marapu. Kematian selalu dilihat sebagai suatu bentuk kemerosotan hidup kini. Tetapi di balik kemerosotan itu ada harapan jiwa mengalami peralihan secara perlahan-lahan menuju cara berada yang baru, tanpa tubuh. Peralihan itu tidak mudah karena jiwa yang lama menghidupi tubuh, kini memulai cara berada yang baru. Dalam pandangan orang Sumba, jiwa itu harus masuk ke dalam kampung Marapu, tempat persekutuan para arwah dan para Marapu. Bila belum berhasil masuk, relasi dengan para Marapu akan terganggu dan aliran kehidupan akan tersendat. Arwah orang mati tampak bersifat ambivalens yaitu bisa mendatangkan a maringi - a malalana (yang sejuk dan segar), dapat pula mendatangkan derita dan kemalangan. Hal ini karena setiap arwah berperanan sebagai kanal yang mengalirkan kehidupan. Bila kanal itu tidak tersambung pada sumbernya yaitu belum tiba di kampung besar Marapu, aliran kehidupan akan tersendat.

Peranan orang hidup tampaknya amat dominan bagi proses masuknya jiwa ke dalam persekutuan dengan para Marapu di kampung leluhur. Jiwa yang telah lepas dari tubuh menurut pemahaman orang Sumba tidak berdaya lagi untuk mengambil tindakan bagi keselamatannya sendiri. Dia pasif, tergantung pada manusia yang melengkapinya dengan bekal, dan menjalankan segala tata cara pemakamannya supaya dia sampai di kampung leluhur. Hal ini berhubungan pula dengan pandangan bahwa jiwa yang terpisah dari tubuh perlu menyesuaikan diri dengan keberadaannya yang baru. Dia mengalami kelahiran baru, ke dalam situasi yang baru karena itu orang yang hidup berperanan mengorientasikannya. Tindakan ini pun berhubungan dengan kebiasaan kehidupan sosial manusia yang saling memberi dan menerima. Orang hidup mengatur segala pemakaman, dan menyediakan bekal bagi perjalanan jiwa menuju kampung besar, juga dengan harapan mereka akan mendapatkan yang sejuk dan segar dari jiwa itu ketika telah selamat. Orang yang hidup tetap berada dalam relasi dengan para arwah orang yang telah meninggal. Jiwa-jiwa orang mati itu menduduki posisi antara, di antara manusia dan para Marapu. Mereka tetap hadir di antara manusia di tengah kampung besar manusia, sekaligus juga hidup dalam komunitas para Marapu di kampung besar Marapu. Oleh karena itu dalam setiap doa dan ritual Marapu, para jiwa leluhur ini yang pertama-tama disapa, sebagai anak tangga pertama menuju ke Marapu yang lebih tinggi, dan pada akhirnya ke Sang Pencipta. 
Kasih karunia Allah secara

Refleksi Teologis: Tema-tema yang sejajar

Dari analisis atas fenomen kebudayaan yang diragakan dalam rangkaian ritual pemakaman, telah diungkapkan di atas tema-tema penting serta nilai utama yang membingkainya. Tema-tema dan nilai itu akan dipertemukan dengan ajaran iman kristen. Dalam pertemuan itu akan tampak kesejajaran makna, juga perbedaan pokok di antara keduanya.

\section{Nilai a maringi - a malalana dan kasih} karunia

Nilai a maringi - a malalana (yang sejuk dan segar) dengan segala kekayaan maknanya yang dialirkan secara vertikal dan horisontal dapat disejajarkan dengan charis (kasih karunia). Charis bersumber dari Allah sendiri dan dianugerahkan kepada umat manusia. Kasih karunia Allah ini bertujuan untuk keselamatan dan damai sejahtera bagi manusia, baik kini di dunia ini maupun di akhirat nanti. Kasih manusia baik kasih yang ditujukan kepada Allah dan kasih di antara manusia merupakan pengambilan bagian dalam kasih Kristus sendiri: "sebagaimana aku telah mengasihi kamu demikian pula kamu harus saling mengasihi" (Yoh 13:34). Karena itu relasi kasih yang dialirkan seorang kepada yang lain adalah pengejawantahan kasih Allah. Allah merupakan "sumber air - pangkal pohon" dari kasih karunia yang mengalir kepada manusia melalui Kristus dan seterusnya dialirkan manusia kepada sesamanya. "Seperti Bapak telah mengasihi aku, demikian juga aku telah mengasihi kamu; tinggallah di dalam kasihku itu" (Yoh 15: 9). konkret dialami manusia melalui kasih sesama manusia. Dalam hal ini, penyalur kasih yang utama adalah orang tua yang menurunkan anak sekaligus mengasuh dan membesarkan anak dengan kasih sayang. Penyaluran itu mengikuti dua alur yaitu garis keturunan ayah tempat bertumbuh dan berlangsungnya kehidupan dan garis keturunan ibu, "sumber air - pangkal pohon". Bila ditelusuri ke atas melalui Ibu dan Bapak, kakek dan nenek dan seterusnya, akhirnya tiba pada "sumber air - pangkal pohon” yang sejati yaitu Sang Pencipta. Karena itulah orangtua dan leluhur yang telah meninggal merupakan kanal untuk tiba ke sumber hidup sejati. Bila orangtua dan leluhur diyakini telah tiba dalam persekutuan dengan Sang Pencipta, mereka sungguh menjadi kanal penyalur charis dari Allah. Demikian pula semua arwah umat beriman lain yang telah mencapai keselamatan, telah "beralih dari tubuh ini untuk menetap pada Tuhan" (2 Kor 5: 8) menjadi penyalur charis dari Allah.

\section{Kampung Marapu dan Surga Kristen} Kampung Marapu dapat disejajarkan dengan surga dalam pemahaman Kristen yaitu status jiwajiwa yang telah hidup dalam kebahagiaan abadi setelah kematian. Menurut pemahaman Marapu, setelah terlepas dari tubuh pada saat kematian, jiwa memulai perjalanan dan pada akhirnya akan tiba di kampung leluhur bila segala ritual pemakaman yang perlu telah dilaksanakan dengan baik. Kampung leluhur itu dipercayai sebagai tempat di mana segalanya mengalami kepenuhan, kelimpahan dan bahagia. Kampung leluhur sebagai tempat kebahagiaan yang penuh, serba 
sempurna dapat disejajarkan dengan surga dalam ajaran Kristen. Namun ada pula perbedaannya. Kampung leluhur digambarkan masih amat duniawi sedangkan surga merupakan suatu keadaan mulia yang melampaui tempat dan waktu.

Bagi iman kristen, keselamatan abadi atau pun hukuman abadi dimulai segera setelah kematian. Keselamatan abadi itulah yang disebut surga sedangkan hukuman abadi adalah neraka. Kompendium Katekismus Gereja Katolik mengungkapkan surga sbb:

"Surga" berarti suatu keadaan bahagia yang tertinggi dan definitif. Mereka yang mati dalam keadaan rahmat Allah dan tidak membutuhkan pemurnian lebih jauh berkumpul bersama Yesus dan Maria, para malaekat dan para kudus. Mereka merupakan Gereja surga, tempat mereka melihat Allah "muka dengan muka" (1 Kor 13: 12). Mereka hidup dalam kesatuan cinta dengan Tritunggal dan menjadi pengantara kita. ${ }^{28}$

Dalam bahasa manusia, surga itu seakan-akan suatu tempat, tetapi sebenarnya Allah, para malaekat dan jiwa-jiwa yang telah selamat tidak membutuhkan ruang. Ruang hanya berlaku bagi badan sedangkan Allah dan para jiwa yang selamat tidak memiliki badan, selain Kristus yang membawa tubuhnya ketika naik ke Surga. ${ }^{29}$ Tetapi

\footnotetext{
${ }^{28}$ Benedictus XVI,Cathechismo della Chiesa Cattolica (Citta del Vaticano: Ibreria Editrice Vaticana, 2005) diterjemahkan oleh Harry Susanto SJ dengan judul Kompendium Katekismus Gereja Katolik (Jakarta Yogyakarta: Konferensi Waligereja Indonesia Kanisius, 2009), no. 209. Selanjutnya disingkat Kompendium KGK dan nomor artikel.

29 Nico Syukur Diester, Teologia Sistematika 2 (Yogyakarta: Kanisius, 2004), hlm. 594.
}

tubuh Kristus di surga juga merupakan tubuh mulia yang tidak lagi dibatasi oleh ruang dan waktu.

Kampung leluhur dalam konsep Marapu dapat disejajarkan dengan surga khusus untuk beberapa aspeknya. Pertama, kampung leluhur sebagai tempat para jiwa yang selamat beristirahat dalam persekutuan dengan Sang Pencipta dan para makhluk mulia dan abadi yang disebut Marapu. Makhluk mulia yang ada bersama Sang Pencipta ini dapat disejajarkan dengan malaekat. Para jiwa yang selamat dapat disejajarkan dengan para kudus. Kedua, kampung leluhur merupakan tempat kebahagiaan tertinggi dan hidup yang serba kelimpahan. Ketiga, jiwa-jiwa yang selamat itu menjadi penyalur "yang dingin dan yang sejuk" yang berasal dari Sang Pencipta kepada manusia. Mereka juga menjadi pengantara antara manusia dan makhluk mulia yang lebih tinggi untuk seterusnya sampai kepada Allah.

Hal-hal yang dikurangi dari konsep "kampung leluhur" adalah aspek gambaran yang amat duniawi. "Kampung leluhur" abadi itu dapat dipahami secara baru menurut perspektif Kristen yaitu sebagai keadaan bahagia yang tertinggi yang akan dialami para jiwa yang selamat dalam persekutuan dengan para kudus, para Malaekat dan Sang Pencipta. Dari sana dialirkan kasih karunia kepada umat manusia di dunia, selain melalui Kristus pengantara utama, juga melalui para Malaekat, Santa Maria dan para kudus, serta para arwah leluhur yang telah selamat.

\section{Perjalanan jiwa ke Kampung Leluhur dan proses pemurnian jiwa}

Dalam pemahaman penganut Marapu, setelah lepas dari tubuh pada saat kematian, jiwa memulai proses 
perjalanan ke kampung leluhur. Proses perjalanan jiwa itu terjadi secara bertahap-tahap dan sebelum masuk ke kampung leluhur, jiwa berada dalam posisi transisi antara orang hidup dan orang mati. ${ }^{30}$ Untuk itulah peranan manusia yang hidup (keluarga) amat penting mengorientasikan jiwa itu dengan doa dan ritual agar dapat menempu jalan yang tepat untuk "memasuki kampung dan melintasi pelataran".

Proses perjalanan jiwa yang berlangsung tahap demi tahap dan posisi transisi sebelum jiwa masuk secara definitif ke kampung besar dapat disejajarkan dengan doktrin katolik tentang pemurnian jiwa setelah mati. Pemurnian jiwa dalam ajaran Katolik digambarkan sebagai purgatory (api penyucian). Api penyucian adalah "keadaan mereka yang mati dalam persahabatan dengan Allah, ada kepastian akan keselamatan kekal mereka, tetapi masih membutuhkan pemurnian untuk masuk ke dalam kebahagiaan surga." ${ }^{31}$ Purgatory bukanlah suatu tempat tersendiri antara surga dan neraka melainkan suatu keadaan transisi. Di satu pihak, orang yang mati itu telah memiliki rahmat untuk keselamatannya sehingga sudah terhitung anggota surga, di lain pihak masih ada kedosaannya juga yang kurang sesuai dengan surga (Diester, 2004: hlm. 600). ${ }^{32}$

Api penyucian merupakan proses pemurnian jiwa. Konsili Trente mengajarkan bahwa jiwa-jiwa di api penyucian dibantu oleh doa kaum beriman terutama kurban Ekaristi yang

\footnotetext{
${ }^{30}$ G.L. Forth, Op. Cit., hlm. 188.

${ }^{31}$ Kompendium KGK, no. 210.

${ }^{32}$ Nico Syukur Diester, Op. Cit., hlm. 600.
}

berkenan kepada Allah (Konsili Trente, dekret tentang api penyucian, 1563, DS 1820). ${ }^{33} \quad$ Konsili Trente tidak menggambarkan api penyucian itu sebagai hukuman tetapi memberi penekanan pada bantuan yang dapat diberikan agar jiwa-jiwa itu dimurnikan dan mencapai keselamatan. Dengan kata lain orang yang meninggal itu telah beriman dan telah mengalami pembenaran tetapi belum seratus persen menjadi orang benar karena itu perlu mengalami proses pembenaran dan pembersihan. ${ }^{34}$

Api penyucian juga dihubungkan dengan pengadilan Allah bagi jiwa individual langsung setelah kematian. Proses penyempurnaan itu terjadi ketika jiwa berhadapan dengan Allah yang kudus. Pada saat kematian manusia melihat dirinya sendiri dalam keadaan yang sesungguhnya. Tetapi kesadaran seperti itu datang dari pihak Allah, sehingga pemurnian itu semata-mata atas karya penyelamatan Allah bukan atas usaha manusia. "Api" menurut tafsian Diester, "dapat dilihat sebagai gambar atau metafor, lambang kemuliaan Allah yang mewahyukan kehinaan manusia, atau pun sebagai kiasan bagi menyalanyalanya kerinduan, bagi berkobarnya hati manusia yang mendambakan Allah". ${ }^{35}$ Di sini penderitaan di api penyucian lebih berupa kerinduan yang amat hebat tetapi belum terpenuhi yaitu belum memandang wajah Allah muka dengan muka.

33 Konsili Trente, Dekret tentang Api Penyucian, dalam Henry Denzinger, Enchiridion Symbolorum, Terjemahan Bahasa Inggris Roy J. Deferrari, The Sourcess of Catholic Dogma (London: B. Herder Book Co, 1957) no. 983.

${ }^{34}$ Nico Syukur Diester, Loc. Cit.

${ }^{35}$ Ibid., hlm. 601. 
Proses perjalanan jiwa menuju "kampung leluhur" dalam pemahaman orang Marapu merupakan pula keadaan transisi dari kehidupan di dunia ini menuju kehidupan baru di luar waktu. Penganut Marapu memang tidak memberi penekanan pada dosa dan ketidak-murnian jiwa sehingga membutuhkan proses perjalanan yang jauh dan tahap demi tahap. Yang mendapat penekanan adalah apa yang dapat dilakukan manusia supaya jiwa itu dapat memasuki kampung leluhur. Walaupun demikian diakui pula bahwa jiwa tidak otomatis tiba di kampung leluhur. Perjalanan itu tidak saja digambarkan jauh tetapi bisa juga jiwa tidak akan masuk ke kampung leluhur itu bila jiwa belum suci dan anggota keluarganya yang masih hidup tidak mengadakan ritual yang tuntas bagi pemakamannya.

Di sini terdapat kesejajaran: proses pemurnian jiwa dan sumbangan atau andil manusia bagi pemurnian jiwa itu agar selamat. Hal yang perlu dikurangi dari pandangan Marapu adalah gambaran dan pemahaman yang bersifat duniawi atas proses perjalanan itu misalnya membutuhkan bekal, kuda tunggang dan anjing yang mendahului di perjalanan. Sementara doktrin Katolik tentang api penyucian lebih memberi penekanan pada penyerahan jiwa ke dalam kerahiman Tuhan yang maha pengampun.

\section{Peranan orang hidup: Ritual Marapu dan liturgi Katolik}

Baik doktrin katolik maupun ajaran Marapu mengakui pentingnya peranan manusia (keluarga atau umat beriman) bagi keselamatan jiwa-jiwa yang masih membutuhkan pemurnian. Peranan manusia itu dilaksanakan melalui ritual dan doa. Ritual dan doa Marapu pada waktu orang meninggal, waktu pemakaman dan sesudah pemakaman dapat disejajarkan dengan upacara dan doa katolik pada kesempatan-kesempatan yang sama.

Dalam tradisi Katolik orang yang mati didoakan, dimakamkan sesuai upacara yang berlaku dalam Gereja dan diadakan kuban misa kudus. Selain itu ada peringatan tiga hari, empat puluh hari atau satu tahun, bahkan hari kematian diperingati setiap tahun dengan doa atau misa kudus. Semuanya ini diadakan dengan tujuan untuk membantu jiwa-jiwa itu agar dapat dimurnikan dan mencapai keselamatan. Kompendium Katekismus Gereja Katolik mengatakan: "Karena ada persekutuan para kudus, kaum beriman yang masih berjuang di dunia ini dapat membantu jiwa-jiwa di api penyucian, dengan mempersembahkan doa-doa untuk mereka, khususnya kurban Ekaristi. Mereka juga dapat membantu mereka dengan beramal, indulgensi, laku tapa dan tobat." $" 36$

Persekutuan para kudus mempunyai dua arti. Pertama, persekutuan umat beriman di dunia ini yang saling membantu untuk mencapai keselamatan. ${ }^{37}$ Kedua, persekutuan antara umat beriman yang kini masih berjuang di dunia ini (Gereja yang berjuang), jiwa-jiwa umat beriman yang masih mengalami pemurnian di api penyucian (Gereja yang menderita) dan jiwa-jiwa yang telah selamat di surga (Gereja yang jaya). ${ }^{38}$ Ketiga bagian Gereja ini membentuk satu kesatuan di mana ketiganya saling mendukung.

\footnotetext{
${ }^{36}$ Kompendium KGK, no. 211.

${ }^{37}$ Kompendium KGK, no. 194.

${ }^{38}$ Kompendium KGK, no. 195.
} 
Umat beriman di dunia (Gereja yang berjuang) mendoakan jiwa-jiwa yang sedang mengalami pemurnian (Gereja yang menderita), sedangkan jiwa-jiwa yang telah selamat di surga mendoakan baik umat beriman di dunia maupun jiwa-jiwa yang sedang dimurnikan di api penyucian.

Ritual dan doa Marapu juga mengungkapkan peranan manusia (keluarga) untuk menolong jiwa orang yang mati agar mencapai kampung leluhur. Dasarnya adalah supaya tetap lancar penyaluran "yang sejuk dan segar" dari para leluhur yang telah selamat kepada keluarganya yang masih hidup. Jiwa yang belum selamat dapat mengakibatkan terhambatnya penyaluran itu. Karena itu jiwa-jiwa yang masih berada dalam proses transisi, yaitu masih dalam perjalanan menuju kampung leluhur, harus ditolong oleh keluarganya yang masih hidup supaya keluarga itu memperoleh kesejahteraan hidup di dunia ini.

Ritual dan doa Marapu dapat disejajarkan dengan doa dan liturgi Katolik. Keduanya merupakan bantuan yang diberikan manusia bagi keselamatan jiwa orang yang mati. Keduanya menyatakan pula kesinambungan saling menolong antara orang yang hidup dan jiwa-jiwa yang telah selamat. Jiwa yang sedang dalam proses transisi (masih dalam pemurnian atau "masih dalam perjalanan") digambarkan pasif dan hanya mengharapkan pertolongan. Hal yang berbeda adalah penekanan pada peranan manusia yang begitu besar dalam paham marapu, sementara dalam ajaran Katolik, penekanan lebih pada penyerahan jiwa ke dalam tangan Tuhan yang maha rahim supaya dimurnikan dan dapat mencapai keselamatan.

\section{Pengantaraan leluhur dan pengantaraan para Kudus}

Leluhur yang telah mencapai keselamatan, menurut pemahaman penganut Marapu, dapat menjadi pengantara antara manusia dan realitas supernatural (Marapu dan Sang Pencipta). Ketika memasuki kampung leluhur, para arwah menjadi penghubung antara manusia dan para Marapu dan seterusnya melalui Marapu tiba kepada Sang Pencipta. Hal ini dapat disejajarkan dengan peranan para kudus dalam ajaran Katolik, yaitu jiwa-jiwa umat beriman yang telah selamat di Surga.

Dalam berbicara tentang persekutuan para kudus, Kompendium Katekismus Gereja Katolik mengungkapkan peranan jiwa-jiwa yang "telah masuk ke dalam kemuliaan Allah" yaitu "mendoakan dan menjadi pengantara kita." ${ }^{39}$ Menurut pemahaman Katolik, pengantara utama dan satusatunya antara Allah dan manusia adalah Yesus Kristus. Dalam kesatuan dengan Kristus, para kudus berperanan sebagai pengantara tambahan. Intinya: manusia mendekati Kristus melalui para Kudus dan selanjutnya melalui Kristus kepada Allah. Peranan pengantaraan para kudus lebih sebagai pendoa bagi manusia, dan tidak pernah menggantikan posisi Kristus sebagai pengantara tunggal. Patut diingat bahwa devosi kepada para kudus adalah salah satu jalan tambahan untuk mendekati Allah. Dalam liturgi resmi Gereja, doa-doa manusia selalu ditujukan kepada Allah dengan perantaraan Kristus dan dalam persekutuan dengan Roh Kudus.

Peranan leluhur yang telah selamat dapat disejajarkan dengan peranan para kudus

\footnotetext{
${ }^{39}$ Kompendium KGK, no. 195.
} 
yaitu pembawa doa-doa manusia kepada Yang Ilahi. Dalam doa Marapu, pemimpin ritual pertama-tama menyapa para leluhur, dan leluhur diminta menyampaikan persembahan dan permohonan kepada para Marapu yang lebih tinggi terutama Marapu pengantara utama yang dinamakan a dikita a noneka (Yang pergi dan yang datang). Marapu "Yang pergi dan yang datang" ini berperanan sebagai pengantara utama karena dia "pergi" membawa harapan dan permohonan manusia kepada Sang Pencipta dan kemudian "datang" membawa "Yang sejuk dan segar" kepada umat manusia.

Hal yang perlu dikurangi dari pandangan Marapu adalah mutlaknya peranan leluhur sebagai anak tangga pertama untuk sampai kepada Marapu dan Sang Pencipta. Dalam ajaran Katolik, yang mutlak adalah pengantaraan Kristus, sedangkan peranan pengantaraan para kudus bersifat tambahan yang harus menyatu dengan Kristus pengantara tunggal.

\section{Kesimpulan}

Dalam kajian perbandingan antara doktrin Katolik dan doktrin implisit Marapu tentang keberlanjutan jiwa setelah mati terdapat kerangka dan tema yang sejajar: kematian - proses menuju keselamatan - keselamatan abadi. Dalam proses menuju keselamatan, jiwa orang mati itu dibantu oleh manusia dengan doa dan upacara. Inti dari usaha manusia adalah membantu jiwa-jiwa agar mencapai keselamatan. Kerangka dan tema seperti itu mendapatkan pengembangan dan pemaknaan khas dalam lingkup masingmasing tradisi dan kepercayaan.
Dalam kepercayaan Marapu, proses yang dialami jiwa menuju keselamatan itu digambarkan sebagai perjalanan jauh dan sulit. Untuk itu dibutuhkan suatu proses pembiasaan jiwa dari keadaan duniawinya (dengan tubuh dan dalam kebersamaan dengan manusia yang hidup) menuju keadaan baru (tanpa tubuh dan dalam kebersamaan dengan para arwah, para makhluk mulia yang disebut Marapu dan dengan Sang Pencipta). Dalam proses transisi ini, para jiwa masih membutuhkan bekal, harta dan segala jenis kelengkapan hidup lain. "Jiwa" dari harta, bekal dan segala kelengkapan hidup itu dipercaya menyertai jiwa manusia dalam perjalanannya menuju keselamatan akhir. Untuk itulah manusia yang hidup berperanan melengkapi jiwa yang menempu perjalanan itu dengan bekal dan harta, dengan doa dan ritual. Keselamatan akhir digambarkan sebagai Kampung Besar, sejajar dengan kampung besar manusiawi. Keadaan kampung besar abadi itu digambarkan serba lengkap, sempurna dan berkelimpahan. Di sanalah jiwa-jiwa masuk dan hidup dalam kebersamaan dengan semua leluhur yang telah meninggal, dengan para Marapu dan Sang Pencipta sendiri.

Tema dosa sebagai halangan untuk mencapai keselamatan akhir secara implisit disebutkan pula dalam ritual Marapu. Dalam ritual boghona uma (menunjukkan rumah kepada jiwa), yang diadakan tiga hari setelah penguburan disebutkan tentang pemurnian jiwa dalam doa yang diucapkan. Para Marapu dimohon untuk memurnikan jiwa orang yang meninggal agar dapat layak masuk ke dalam kampung besar.

Dalam pandangan Katolik, keselamatan manusia dihubungkan dengan rahmat 
Allah yang menyelamatkan. Segera setelah kematian, jiwa manusia menghadap pengadilan ilahi. Bagi jiwajiwa yang suci, yaitu mereka yang meninggal dalam rahmat dan persahabatan dengan Allah, langsung menikmati kebahagiaan abadi di Surga. Bagi jiwa-jiwa yang terpisah dari rahmat Allah karena dosa berat, langsung mengalami hukuman abadi yang disebut neraka. Sedangkan jiwa-jiwa yang meninggal dalam rahmat Allah tetapi tidak cukup suci, masih membutuhkan pemurnian yang disebut api penyucian, sebelum akhirnya masuk surga. Untuk pemurnian jiwa-jiwa itu, dibutuhkan bantuan doa-doa umat beriman yang masih hidup terutama dengan kurban Ekaristi. Selain doa-doa umat beriman yang masih hidup, iman Katolik akan persekutuan para kudus mengakui pula peranan doa-doa para kudus di surga demi keselamatan jiwa-jiwa di api penyucian.

Dari sejumlah kesejajaran antara doktrin Katolik tentang eskatologi intermedia dan doktrin Marapu tentang keberlanjutan jiwa setelah mati yang digambarkan di atas, dapat dikonstruksi perjumpaan kedua doktrin. Pengandaian pertama dalam konstruksi ini adalah pandangan yang positif atas kepercayaan Marapu sebagai jalan otentik bagi orangorang Loura untuk menggapai misteri ilahi. Pandangan positif ini meliputi keberanian menerima sejumlah istila dalam agama Marapu, walaupun telah lama dalam pandangan Katolik dianggap berhala atau kekafiran. Istila-istila tersebut dipertahankan, sambil diberi pemaknaan baru dalam kekristenan, bila perlu. Pemaknaan baru itu meliputi pengurangan unsur-unsur yang bertentangan dengan doktrin Kristen dan penambahan unsur-unsur Kristen yang tidak terdapat dalam doktrin Marapu. Sedangkan unsur-unsur yang telah sama di antara keduanya dibiarkan seperti adanya dalam kepercayaan Marapu. Berdasarkan hal ini, dapat dibangun suatu doktrin Katolik tentang eskatologi intermedia yang telah diinkulturasikan. Dalam eskatologi intermedia inkulturatif ini, Surga dapat disebut "Kampung leluhur", api penyucian dapat disebut proses perjalanan menuju kampung besar, doa dan upacara di sekitar kematian dapat disusun dengan mengakomodasi simbol dan doa dari kepercayaan Marapu.

Kampung leluhur sebagai tujuan terakhir jiwa-jiwa dipahami secara baru menurut perspektif Katolik yaitu sebagai keadaan jiwa-jiwa yang mengalami kebahagiaan tertinggi karena bersatu dengan Sang Pencipta, dan dalam persekutuan dengan para Malaekat dan para Kudus. Para leluhur yang diyakini telah selamat dapat digolongkan di kalangan para Kudus. Kampung besar ini tidak lagi dipahami sebagai tempat nyata tak kasat mata yang masih berada di dunia ini (di Tanjung Sasar), melainkan berada di luar kriteria ruang dan waktu. Karena itu jiwa-jiwa yang selamat tidak membutuhkan harta apa pun.

Dari Kampung leluhur ini mengalir "Yang sejuk dan segar" (charis) secara terus menerus kepada umat manusia, karena para leluhur dan para kudus yang telah hidup di hadirat Sang Pencipta menjadi pendoa bagi manusia. Selanjutnya "yang sejuk dan segar" itu diteruskan oleh manusia kepada sesama dan kepada segenap unsur alam. Relasi manusia dan "Kampung leluhur" abadi itu dipelihara dengan liturgi dan doa, termasuk devosi kepada para kudus dan para Malaekat. 
Aspek transisi dari jiwa orang yang meninggal sebelum mencapai keselamatan, amat kuat mendapatkan penekanan dalam kepercayaan Marapu. Aspek transisi ini dipahami secara baru dalam perspektif Katolik sebagai penyucian jiwa sebelum mencapai keselamatan. Penyucian ini lebih dipahami sebagai karya Allah yang maha rahim dan karya penebusan Kristus, bukan pertama-tama karena perbuatan manusia melalui doa dan ritual. Doa dan kurban misa kudus bertujuan memohon kerahiman Tuhan untuk memurnikan jiwa agar memasuki keselamatan abadi. "Bekal" yang perlu bagi "perjalanan" pemurnian jiwa adalah doa, Ekaristi kudus dan karya amal dari manusia beriman yang masih di dunia.

Pemahaman baru atas "perjalanan jiwa" dan "Kampung Leluhur" sebagai tujuan terakhir perjalanan jiwa menurut perspektif Kristen selanjutnya diaplikasikan dalam doa di sekitar kematian dan upacara liturgi pemakaman. Doa dan liturgi pada dasarnya bertujuan membantu jiwa-jiwa agar selamat tiba di "Kampung Leluhur". Namun bantuan itu tidak memutlakkan peranan manusia melainkan peranan Allah yang maha rahim, dan karya penebusan Kristus. Yang berperanan sebagai a panuduna lara (yang menunjukkan jalan), bukan manusia tetapi Kristus. Manusia hanya berperanan mempercayakan jiwa yang meninggal ke dalam tangan Tuhan yang maha rahim dan menyelamatkan.

\section{Daftar referensi}

Benedictus XVI, Cathechismo della Chiesa Cattolica (Citta del Vaticano: Ibreria Editrice Vaticana,
2005) diterjemahkan oleh Harry Susanto SJ dengan judul Kompendium

Katekismus Gereja Katolik (Jakarta - Yogyakarta: Konferensi Waligereja Indonesia - Kanisius, 2009)

Boli Ujan, B dan G. Kirchberger

(Ed.), Liturgi Autentik dan Relevan (Maumere: Ledalero, 2006).

Bungin, B., Penelitian Kualitatif Komunikasi, Ekonomi, Kebijakan Publik, dan Ilmu Sosial Lainnya (Jakarta: Kencana, 2009).

Denzinger, H., Enchiridion Symbolorum, Terjemahan Bahasa Inggris Roy J. Deferrari, The Sourcess of Catholic Dogma (London: B. Herder Book Co, 1957)

Diester, N.S., Teologia Sistematika 2 (Yogyakarta: Kanisius, 2004).

Forth, G.L., "Rindi, an Ethnographic Study of a Traditional Domain in Eastern Sumba", dalam Verhandelingen van het Koninklijk Instituut voor Taal-, Land en Volkenkunde 93 (The Hague: 1981).

Haripranata, H., Ceritera Sejarah Gereja Katolik Sumba dan Sumbawa, (Ende: 1984).

Hesselgrave, D.J dan Edward Rommen, Kontekstualisasi: Makna, Metode dan Model, Terjemahan Stephen Suleeman (Jakarta: BPK Gunung Mulia, 2004).

Hoskins, J, "So my name shall live: Stone-dragging and Grave-building in Kodi, West Sumba", dalam Bijdragen tot de Taal-, Land en Volkenkunde, 142 (The Hague: 1986).

The Play of Time, Kodi Perspectives on Calendars, History and Exchange (Berkeley: University of California Press, 1993). 
Iskandar, Metodologi Penelitian Kualitatif (Jakarta: Gunung Persada Press, 2009)

Kirchberger, G. dan John M. Prior (eds.) Iman dan Transformasi Budaya (Ende: Nusa Indah, 1996)

Nudu, N.A.M., Pertemuan Marapu dengan Yesus Kristus (Skripsi, Yogyakarta: 1983)

, "Iman Kristiani dan Marapu" dalam Kaleidoskop Gereja Katolik Sumba dan Sumbawa 18891989, (Weetebula: Panitia Perayaan Seratus Tahun Gereja Katolik di Sumba, 1989), hlm. 92-99.

Panda, H.P., "Usaha Penyesuaian Liturgi dalam Budaya Sumba dan Konteks Kepercayaan Marapu", dalam Boli Ujan B. dan G. Kirchberger, Liturgi Autentik dan Relevan (Maumere: Ledalero, 2006).

, "Mengapa Orang Katolik Masih Menjalankan Ritual Marapu? Menguak Praktik Iman Ganda di Loura" dalam Jurnal Ledalero, Vol. 13, No. 1, Juni 2014.

Pieris, "Interreligious Dialogue and Theology of Religions: An Asian Paradigm", dalam East Asian Pastoral Review 29 (1992), 365-376.

Prior, J.M., Bejana Tanah Nan Indah: Refleksi Sosio-Budaya atas Jemaat-Jemaat Basis Nusa Tenggara Sebagai Wujud Evangelisasi Baru (Ende: Nusa Indah, 1993).

Wellem, F.D., Injil dan Marapu, suatu Studi Historis-Teologis tentang Perjumpaan Injil dengan Masyarakat Sumba pada Periode 1876-1990, (Jakarta: BPK Gunung Mulia, 2004).

Woga, E., Der Parentale Gott: Zum Dialog zwischen der Religion der indonesischen Völker Sumbas und dem Christentum (Nettetal: Steyler Verlag, 1994).
Yohanes Paulus II, Paus, Redemptoris Missio, Ensiklik (7 Desember 1990), Terjemahan Marcel Beding (Ende: Nusa Indah, 1992). 